\title{
Frontier Model of Large Scale Full Mechanized Hybrid Rice Farming System at Irrigated Rice Field in Indonesia
}

\author{
I. M. O. Adnyana ${ }^{1}$, I. G. M. Subiksa ${ }^{2}$ I. M. J. Mejaya ${ }^{1}$ \\ ${ }^{1}$ Indonesian Centre for Food Crop Research and Development (ICFORD) Jl. Merdeka 147, Bogor 16111, \\ Indonesia \\ ${ }^{2}$ Indonesian Centre for Agricultural Land Resource Research and Development (ICALRRD), Jl.Tentara Pelajar \\ No.12, Bogor 16111, Indonesia
}

*Corresponding Author: I. M. O. Adnyana, Indonesian Centre for Food Crop Research and Development (ICFORD) Jl. Merdeka 147, Bogor 16111, Indonesia

\begin{abstract}
Indonesia rice self sufficiency targeted goal may not be realistic if mainly depend upon Java with population almost half of Indonesia from total population at about 240 million people in 2013. It is a right time then to find out a frontier model of rice production technology in Indonesia for newly open area or corporate farming to meet increasing rice consumption in line with population increase. With estate approach and or consolidation of rice farming management for small scale farmers in a corporate frontier model could increase farmer bargaining position. The objectives of this study is to: (1) measure the hybrid rice adaptability to the location specific agro-climate condition, (2) verify and validate rice production technology in a frontier model of large scale full mechanized rice farming, and (3) analyse the financial feasibility level of large scale full mechanized hybrid rice farming. Best Management Practices (BMP) was exercised in a demonstration farm (dem-farm) approach to evaluate and analyse this rice production frontier model in-demfarm-activities. Dem-farm is conducted at 12.3 ha at nearly level rice plot size in PT. Sang Hyang Seri rice field, Sukamandi, Subang District, West Java in second dry cropping season (June-October 2014). The output of dem-farm showed that large scale full mechanized rice farming is highly prospective to be outreached at newly open area with estate and or corporate farming approach for existing farmers group. However, for large scale field practices, some component technologies need to be improved especially: GPS guided land levelling; crop needs base water management, and weed management. Average hybrid rice yield is about 10.29 ton/ha that significantly higher compared with inbred rice yield of 8.71 ton/ha. On the other hand, financial analysis outputs showed that this frontier model of large scale rice farming practices is financially feasible with $R / C$ and $B / C$ ratio is 2.23 and 1.23 , respectively, while marginal $B / C$ ratio $(M B C R)$ is 2.97 compared with farmer practices.
\end{abstract}

Keywords: technology verification, large scale, mechanized, hybrid rice.

\section{INTRODUCTION}

Population rich but land hungry countries like China, India and Indonesia have no option except to produce more food grains and other agricultural commodities per units of land and water under conditions of diminishing per capita availability of arable land and irrigation water, but expanding biotic and abiotic stresses. Such a challenge can be met only by harnessing the best in frontier technologies and blending them with our rich heritage of ecological prudence. Ecotechnologies for an Ever-green revolution should be the bottom line of our strategy to shape our agricultural future (Swaminathan 2005). What nations with small farms and resource poor farmers need is the enhancement of productivity in perpetuity, without associated ecological or social harm. The green revolution launched in 1060s should become an ever-green revolution rooted in the principles of ecology, social and economic by consolidating the farm management in a cooperative system.

Therefore, large-scale farming may take advantage of economies of scale to produce safe, wholesome food at relatively low cost to hundreds of millions of people worldwide. At the same time, large-scale farming can present challenges to the long-term viability of social, agronomic, and environmental systems. Given these well-documented challenges, actively involved people discuss best approaches to ensuring future food security while protecting environmental, agronomic, and social systems. Of 
interest to researcher is the extent to which: 1) various agricultural systems affect social systems, and 2) communities maintain a sense of sound neighbouring within the context of sometimes heated debates about best practices for large scale food production system (Sapp, 2012). Large scale farming have many apparent advantages: (1) large scale operation permits specialization and division of labour, (2) buying and selling in large volume, (3) reduction of overhead and fixed charges of investment, and (4) more economical use of large and specialized machinery (Stephen, 2010 and Stephen, 2012).

A larger-scale approach to sustainable farming could be more beneficial for bio-diversity than current system of farm-based agro-environment payments. Conservation of populations of animals and plants requires planning across the landscape, because it is at this scale - not the farm scale - that many ecological processes happen. "Reform of the Common Agricultural Policy will provide an important opportunity to create sustainable food production and a landscape, as it is championing 'sparing land' from food production on each farm to contribute to environmental aims.

Rice production technology especially for hybrid rice varieties is basically developed based on the location specific agro-climate and environment suitability. All suitable component technologies than are packaged into so called integrated crop and resource management (ICRM). Implementation of ICRM following Best Management Practices (BMP) approach that comprised of: (1) land levelling, (2) land preparation, (3) planting with two techniques such as direct seeding or transplanting, (5) water management, (6) nutrient management, (7) crop health with integrated pest management, (8) appropriate harvesting, and (9) post harvest handling and processing. Before implementation of ICRM in a large scale and full mechanize rice farming, technology verification and validation is necessary in order to find out most suitable GAP at the targeted areas (IRRI 2013).

Demonstration farm (Dem-Farm) is one of the media that can be used to verify and validate component technologies packaged in the Good Agriculture Practice (GAP) for hybrid rice farming in a larger scale compared with an ordinary trial. Simulation of GAP is than conducted at location with climate and environment which is basically location specific. This technology verification and validation is crucially important if large scale full mechanized rice farming is then outreached to the newly open areas or in corporate farming system. With respect to rice science and technology (rice $\mathrm{S} \& \mathrm{~T}$ ) this model is considered as a frontier rice farming practices especially in Indonesia as one of the main rice producing country in the world. Therefore, the objective of this dem-farm are: (1) measure the hybrid rice adaptability to the location specific agro-climate condition, (2) verify and validate production technology for large scale mechanized rice farming, and (3) analyse the financial feasibility level of large scale mechanized hybrid rice farming.

\section{Material And Method}

\subsection{Demonstration Farm}

\subsubsection{Location and Topographic Survey}

Demonstration farm of large scale rice farming technology was conducted at PT. Sang Hyang Seri Farm in Sukamandi, Subang District, and West Java. Topographic survey was conducted to guide the land levelling activities in order to make rice field as level as possible. Ground station equipment was used to determine the areas to be cut and filled. Covered area of topographic survey is about $12.6 \mathrm{ha}$.

\subsubsection{Material}

Three hybrid rice varieties were tested in this dem-farm that consisted of GH-21, SL-8 SHS, and Hipa-14 while Ciherang inbred rice variety was used as check. Total area of dem-farm was about 12.6 hectares. Those varieties were introduced by PT. SAS in collaboration with Guo Hao Seed Industry Ltd., PT. Sang Hyang Seri, and Indonesia Centre for Rice Research (Table 1). Other inputs like fertilizer (NPK and organic fertilizer) were given based on crop need in accordance with soil tool kit for $\mathrm{P}$ and $\mathrm{K}$, and leaf colour chart for urea in an integrated site specific nutrient management (SSNM). While water supply to rice crop followed intermittent irrigation technique based on crop growth stages (IRRI 2013). Chemical to control pest and diseases was based on economic threshold unless there were endemic attacks. 


\section{Method}

\subsection{Land Levelling and Preparation}

GPS guided land levelling technique supported by suitable machine and equipment has been practiced because it closely related to the following aspects and parameters namely: (1) land looks level but wide topographic variation exists, (2) wide variability in crop yields at field/block/ production centre area or zone level, (3) for better water distribution and water savings, (4) for improvement in nutrient use efficiencies to meet what the crop needs, (5) option for precision farming, and (6) higher crop productivity and better yield quality (Depart of Soil \& Water Conservation, India 2008; IRRI 2003; Rickman 2002). For example, the field particulars, such as length and width related to the selected rice plot for 100 meter x 60 meter $\left(\mathrm{L} \mathrm{x} \mathrm{W)} \mathrm{with} \mathrm{an} \mathrm{average} \mathrm{area} \mathrm{of} 6,000 \mathrm{~m}^{2}\right.$ was then significantly reduced levels before levelling for better water distribution (Anuraja et al., 2013).

Table1: Type and source of rice varieties, and planted area in Sukamandi, 2014.

\begin{tabular}{|l|l|l|}
\hline Variety & Area (ha) & Remark \\
\hline Hybrid rice & & \\
\hline GH-21 & 4.00 & PT. SAS (Guo Hao) \\
\hline SL-8 SHS & 4.00 & PT. SHS \\
\hline Hipa-14 & 3.94 & ICRR \\
\hline Inbred rice & & \\
\hline Ciherang (check) & 0.66 & ICRR \\
\hline Total & $\mathbf{1 2 . 6 0}$ & \\
\hline
\end{tabular}

Source: Guo Hao, PT. SHS (2012); Indonesia Centre for Rice Research (2014).

Land preparation for rice dry seeding practices were consisted of ploughing or rotavating followed by harrowing and levelling of dry and friable soil. Dry land preparation does not require irrigation water because it can be done when the soil has the correct water contact and is friable for ploughing or rotavating and harrowing. Therefore, land preparation under dry soil condition in this large scale rice farming demonstration farm in Sukamandi was carried out twice such as: First, using offset disk harrow that pulled by $90 \mathrm{HP}$ tractor to flow land at about $20 \mathrm{~cm}$ dept. Second, using rotary tiller (rotavator) for land preparation to smoothing out the land surface. The second land preparation was also aimed to further improve the land level before direct seeding under dry soil condition was exercised.

\subsection{Direct Seeding Technique Under Dry Soil Condition}

For the purpose of large scale and mechanized rice farming at irrigated rice area, multi-purpose direct seeder was attached to $80 \mathrm{HP}$ tractors. This multi-purpose direct seeder also equipped with ditcher that mainly exercised to dig the micro canal at every $2.5 \mathrm{~m}$ distance with the same direction to the seed rows. The ditcher was installed at the middle of the 10 rows direct seeder to meet the requirement for micro canal in large scale rice farming. Seeder was attached to the tractor wheel in combination with hydraulic system to control drop of the seed per hill. Multi-purpose direct seeder installation was completed and ready to be calibrated.

Treated seed and NPK fertilizer were placed in its consecutive box. The fertilizer was dropped about 5 $\mathrm{cm}$ apart of seed at the same time during seeding. Direct seeding activities started including basal fertilizer application and micro canal at the middle for every $2.5 \mathrm{~m}$ distance. Soil covered seed rows and micro canal are well done at the rice field for better irrigation and drainage system. Micro canal with $20 \mathrm{~cm}$ width and $15-20 \mathrm{~cm}$ depth is helpful to irrigate and drainage large scale rice farming. Refilling seed and NPK fertilizer for next direct seeding, basal fertilizer application and ditching activities.

\subsection{Water Management}

Intermittent irrigations were practiced in this experiment for the different periods of rice crop growing from pre-planting, early vegetative stage, productive stage, to the ripening stage (IRRI 2013). Water discharge to irrigate rice field of hybrid rice is in between 0.6 to 1.2 litre per second based on the crop need and growth stages. Rehabilitation of quarterly canal used backhoe for $1,450 \mathrm{~m}$ canal. Both irrigation and drainage canal were improved to secure the inlet and outlet water flows are functioning 
well. The formation of micro canal at every $2.5 \mathrm{~m}$ was carried out during seeding activities together with basal fertilizer application by the multi-purpose direct seeder. Micro canal with $20 \mathrm{~cm}$ wide and $20 \mathrm{~cm}$ dept established during the direct seeding activities to improve the water distribution during crop growing period.

\subsection{Nutrient Management}

Nutrient management is following the concept of feed the crop need in an integrated site specific nutrient management (SSNM). SSNM provides scientific principles for optimally supplying rice with essential nutrients. It enables rice farmers to tailor nutrient management to the specific conditions of their field, and it provides a framework for nutrient best management practices for rice (IRRI 2013). For example, based on the soil analysis output at the dem-farm rice plot, basal fertilizer application of $350 \mathrm{~kg} / \mathrm{ha}$ compound NPK fertilizer is carried out at the same time with direct seeding activities under dry soil condition. Top dressing fertilizer with urea granule at $250 \mathrm{~kg} / \mathrm{ha}$ is carried out at 30 days after seeding (DAS). SSNM has potential for improving yields and nutrient efficiency in irrigated rice to close existing yield gaps. The major challenge for SSNM will be to retain the success of the approach while reducing the complexity of the technology as it is disseminated to farmers. The nature of the approach will need to be tailored to specific circumstances in different countries. In some areas, SSNM may be field or farm specific, but in many areas it is likely to be just region and seasonspecific (Dobermann et al., 2002; Pampolino et.al. 2007).

Before fertilizer application is carried out, soil surface was under saturated condition for more effective fertilizer application. Nutrient status of rice plant is monitored by using leaf colour chart (LCC) especially Nitrogen during grain filling. Meanwhile, Soil Tool Kit is used to determine the status of Phosphorous (P) and Potassium (K) at the beginning of Best Management Practices (BMP) implementation. Before seeding, seed has been treated by insecticide (Carbosulfan) to control insect during germination and early vegetative growth.

\subsection{Integrated Pest Management}

Major pest threated during the cropping season were stem borer, brown plant hopper and rats. Stem borer outbreak was occured sorounding the planted area, so that most of PT. SHS area do replanting. Control this main insect was carried out by spreading Carbofuran and Fipronil. Rat population outbreak commonly occur on July - September, therefore trap barrier system (TBS) was used to trap rat. Plastic fence was also established at the border area of rice plot that equipped with rat trap to further protect rice plant from rat attack.

Seed treatment was also applied to control insect attack during the vegetative growth stage. Fipronil (Reagent) was applied to prevent stem borer attack during tillering stage. Light trap was used to monitor the insect population dynamic as an early warning system approach. Anticipative chemical control can be applied in accordance with the early warning output.

\subsection{Financial Analysis}

Financial analysis is exercised to analyse the financial feasibility of large scale full mechanize rice farming at an area of about 12.6 hectares with direct seeding under dry soil condition and optimal application of technology components. Average on-farm hybrid and Inbred rice yield (ton/ha) wet grain is used as the main output with respect to agricultural inputs used per hectare. $\mathrm{R} / \mathrm{C}$ ratio is exercised to analyse the financial feasibility of this large mechanized rice farming with recorded cost component that include fixed cost and variable cost (Swastika 2004). The following formulas are used to analyse on-farm income and its financial feasibility (Muhammad et al. 2012 and Marimin 2014).

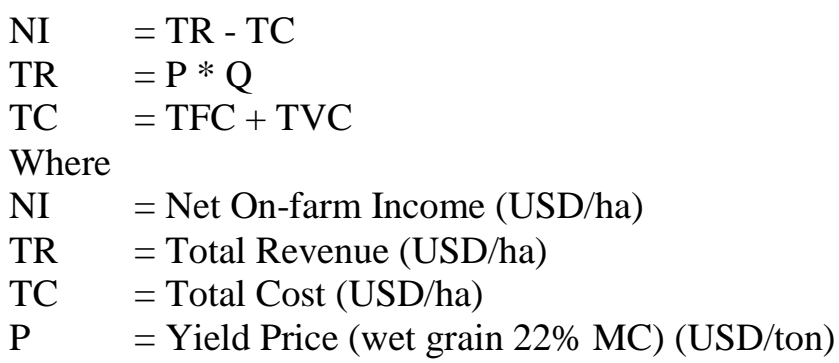




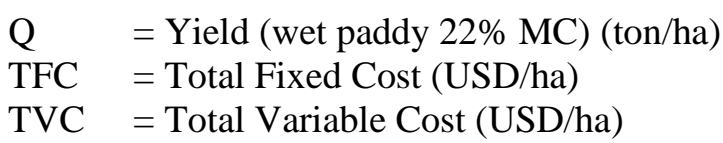

Fixed cost includes land rent and water management, and variable cost include all operational cost component that include: seed, fertilized, chemical, and hard labour.

To analyse the financial feasibility level of this dem-farm, the following formula is then exercised:

$\mathrm{R} / \mathrm{C}$ Ratio $\quad=\mathrm{TR} / \mathrm{TC}$ or

$\mathrm{B} / \mathrm{C}$ Ratio $\quad=\mathrm{NI} / \mathrm{TC}$

If $\mathrm{R} / \mathrm{C}>1.0$ or $\mathrm{B} / \mathrm{C}>0.0$ then large scale mechanized rice farming technology demonstrated in this dem-farm is financially feasible that can be developed in situ or outreaching to other irrigated rice area. On the other hand, if $\mathrm{R} / \mathrm{C}<1.0$ or $\mathrm{B} / \mathrm{C}<0.0$, this indicated that this technology is not feasible to be developed further. On the other hand, in order to measure the additional benefit that gained by large scale, mechanized rice farming with respect to the farmer practices, MBCR (marginal benefit cost ratio) then exercised as follow:

$$
\text { MBCR }=\frac{\text { Total Gains }}{\text { Total Losses }}
$$

Where:

Total Gains $=$ Total additional income gained from introduced technology

Total Losses $=$ Total additional cost expended due to application of introduced technology .

If MBCR > 1, the introduced technology (introduced hybrid rice varieties) is financially feasible to be scaling up in situ or out reaching to newly open area. Otherwise, if MBCR $\leq 1$ then hybrid rice varieties did not feasible or the introduced technology just the same with farmer practices or even worst.

\section{RESULTS AND DISCUSSION}

\subsection{Pre Planting and Seeding Performance}

\subsubsection{Pre Planting}

For land levelling process for this demonstration farm, land was ploughed by using Rome plough to break the soil with $20 \mathrm{~cm}$ depth in average. Rome plough was also used for field cut and fill activities as well as to remove levees. Grader was mainly used to level the land and move soil from cut soil to fill part of the rice field. Those land levelling activities are under GPS control. Soil type belongs to clay so that slightly hard to cut and need more time including the removal of levees. Rotavator is exercised to smoothing out the soil clod into smaller particles and improve the land level condition. The outputs showed that the level of land differences is $0.05 \%$ to $0.075 \%$ from East to West side of rice plot with distance of about $150 \mathrm{~m}$. Therefore, the submergence of rice field at $10-15 \mathrm{~cm}$ for vegetative growth was effectively suppressed weed growth.

Land levelling improves uniformity of crop growth and yield. It conserves soil and water by creating slight, but uniform, slope gradients to improve drainage, drive irrigation water across the field, facilitate more even distributions of irrigation water, and improve the effectiveness of surface irrigation. Land levelling exercised in this dem-farm is the main agricultural practice to facilitate more uniform distribution of irrigation water. Applying equal amount of irrigation water on overall land with heterogenic soil properties alone may not be enough for productivity. Therefore, after levelling, some other site specific cautions for defining and refining management practices to regain productivity and for improving homogeneity in soil properties are needed (Tekin Öztekin. 2013).

As per studies, a significant (20-25\%) amount of irrigation water can be served due to proper farm designing and evenness of the fields. Fields that are level or nearly level have homogenous crop stands, decreased weed burden and proper crops maturity. All these factors lead to increased yield and better grain quality (Department of Soil \& water Conservation, 2008). Rice growers at surrounding 
area also recognize this and therefore devote considerable time resources in levelling their fields properly. However, traditional methods of levelling land are cumbersome, time consuming and more expensive.

\subsubsection{Seeding Performance}

A well-levelled field is a prerequisite for proper direct seeding, water and crop management. When field are not level, water may stagnate in the depressions whereas higher parts may fall dry. This results in uneven crop emergence and uneven early growth, uneven fertilizer distribution, and possibly additional weeds (IRRI 2013). However, effective land levelling output showed that: (1) improve homogeneity of seeding performance and crop establishment, (2) reduce the time and water required to irrigate the field by $20-25 \%$, and (3) ensure more uniform distribution of water in the field.

Less seed needed per hectare for higher germination rate (> 90\%) since number of seeds per hill also lower (at least 3 seeds per hill). Multi-purpose direct seeder is ready to carry out seeding activities in demonstration farm (dem-farm) at PT. SHS rice field. Direct seeder calibration at the rice field was done to evaluate the seed drop per hill and seed spacing. Seed spacing is $25 \mathrm{~cm}$ between rows and $15 \mathrm{~cm}-18 \mathrm{~cm}$ within row so that the plant population is approximately about 220,000 plants with 25 $\mathrm{kg}$ seed per hectare.

The labour intensive and costly method of transplanting could be substituted by direct-seeding with no sacrifice in productivity by effective water control (Johnkutty et al., 2002). The weed hazard associated with the direct seeding has been decreased $80-90 \%$ by integrated application of herbicides and proper water management. Considering the advantages of getting adequate plant population, desired crop geometry and easiness in weeding, placement of seeds by multi-purpose Bokto seeder such as: placing seed 3-5 cm bellow land surface, cover the seed with soft soil, and micro canal establishment at every $2.5 \mathrm{~m}$ distance showed more uniform direct seeding rice performance. However, it warrants more detailed investigations on direct seeding with respect to seed rate, spacing, variety suitability, weed management, water control, land preparation and other associated management aspects (IRRI 2013).

\subsection{Crop Performance}

\subsubsection{Crop Performance at 35 Days After Seeding}

Ditch or micro canal made by multipurpose direct seeder during seeding activities functioning as expected and rows spacing of $25 \mathrm{~cm}$ still can be seen clearly. However, it might need wider rows since plant population look densely. About $30 \mathrm{~cm}$ between rows and $15 \mathrm{~cm}-18 \mathrm{~cm}$ in row spacing need to be tested to find out the ideal plant population per hectare. Even though direct-seeded rice systems have several advantages, weeds remain as one of the major biological constraints in these systems. Research outputs showed that time need for land preparation was significantly reduced in direct seeded (DS) compared with transplanting (TP) rice. This led to a significant reduction in irrigation and total water input before crop establishment. Over the whole cropping season, the three crop establishment methods had a similar total water input, but DS had significantly less irrigation water and higher water productivity with respect to irrigation water than TP (Cabangon 2002). Good water management in lowland rice focuses on practices that conserve water by eliminating the unproductive water flows of seepage, percolation, and evaporation) while ensuring sufficient water for the crop.

However, there is a need to integrate different weed management strategies and water resource management to achieve effective and sustainable weed control in direct-seeded rice systems. This finding describes different techniques, including preventive and cultural approaches, to manage weeds in these systems that will help researchers and extension specialists to develop integrated weed management programs for direct-seeded rice systems (Zeigler in Chauhan 2012). As weed is one of the major constraints in direct seeding under dry soil condition then to minimize weed growth, some efforts have been applied following Chauhan 2012 such as: 1) applaying pre germinate, early germinate and post germinate herbicide; 2) flooding the rice field during the vegetative growth of rice plant, and 3) apply mechanical weeding.

Main type of weed grow in this cropping season is grassy weed type namely Echinocloa crugalli (jejagoan) Echiocloa colunum (jejagoan kecil) and Leptochloa sp (grintingan) which is similar with 
rice plant morphology. Others weed type are Cyperus sp (teki-tekian) and broad leaf weeds. Applying herbicide like Ricestar for 1.0 litre/ha was able significantly reduced the development of grass type weed. Selective herbicide spraying was also executed to eradicate weeds selectively both wide and narrow leaf weeds.

Crop performance at 35 DAS remain as expected such as green leaf with 12-20 tillers per hold. Densely plant population due to more seed per hold exercised during seeding as an impact of germination rate $80-85 \%$ with seed requirement $35 \mathrm{~kg}$ per hectare. This need to be corrected for next season cropping, as higher germination rate (>90\%) the seed requirement is predicted about $20-25 \mathrm{~kg}$ per hectare. In addition, micro canal is functioning as expected to irrigate and distribute water evenly as well as drainage rice field periodically in line with fertilizer and pesticides application.

\subsubsection{Crop Performance at 50 Days after Seeding}

Crop performance of 3 varieties tested in this demonstration farm 50 days after seeding that consisted of GH-21, SL-8 SHS, and Hipa-14 were agronomic ally suitable. Plant population look too densely and crops flag leafs still look green and homogenous. Reducing the use of seed from about $35 \mathrm{~kg} / \mathrm{ha}$ to $25 \mathrm{~kg} / \mathrm{ha}$ in direct seeding under dry soil condition may considered as one of the option to reduce the plant population.

Spreading Carbofuran and Fipronil has decreased stem borer attack until 80\%. BPH infestation occured because of no similar planting time across planted area and chemical control was done effectively by spraying BPMC and Applaud. In addition, water pumping and fumigation were also carried out to control rat. At least 9 rats in average was caught everyday per TBS out of 4 traps installed at the rice field. Meanwhile, the main diseases infestation is Bacterial Leaf Streak (BLS) caused by Xanthomonas campestris which infested rice flag leaf in grain filling stage. Other diseases observed during the seasson are tungro and grassy stunt. All diseases were controlled by using Nativo fungicide mixed with grain booster.

\subsubsection{Crop Performance at 95 Days After Seeding}

Rice crop performance at 95 days after seeding showed that GH-21 hybrid rice variety introduced by Guo Hao Seed Industry grows well without BLB infestation. Number of panicles per hill is between $12-15$ units and number of grains per panicle is about 215 in average. At 95 DAS, rice flag leaf of GH-21 still look green and this indicates that grain filling is still in process. On the other hand, SL8SHS hybrid rice variety produced by PT. Sang Hyang Seri with crops duration is about 110 days. Crop performance is physically looking good without BLB infestation with number of panicles between $14-18$ units per hill and number of grains per panicle is about 193 in average.

Meanwhile, Hipa 14 hybrid rice that released by Indonesian Centre for Rice Research (ICRR) has longer crops duration compared with 2 others hybrid rice varieties. Until 95 DAS, a part of crops still green. There is stem borer infestation at about $5 \%$ of the total plant population. Number of panicles between $13-16$ units per hill and 198 grains per panicle in average. However, rat begins attacking rice crop thereafter until 105 DAS with intensity 5-10\% from the total plant population. Rat population out break during August-September and this must be taken into account when this large scale rice farming model out reached into newly open area (ICRR, 2010).

\subsection{Yield Performance}

Production of conventional puddle transplanted rice is facing severe constraints because of water and labour scarcity and climatic changes. Direct-seeded rice (DSR) is a feasible alternative to conventional puddle transplanted rice with good potential to save water, reduce labour requirement, mitigate green-house gas (GHG) emission and adapt to climatic risks (Durga 2011). The yields are comparable with transplanted rice since crop was properly managed during the demonstration farm activities as carried out at PT. Sang Hyang Seri on-farm land.

Harvest was executed when the grain maturity at least $95 \%$ of the total number of panicles. Harvest was done by using combine harvester that need 1 operator and 1 assistant operator. Specification of combine harvester are: (1) track with rubber crawler, (2) cutting width $180 \mathrm{~cm}$, (3) movement: 60 $\mathrm{m} /$ minute, (4) manual bagging, (5) limited grain tank, (6) no cabin operator, and (7) work capacity about 2 hectares per day with 8 working hours. 
The potential yield of GH 21 is about 10.59 ton/ha which was slightly lower than SL8SHS with yield about 10.83 ton/ha. The lowest potential yield is Hipa 14 or about 9.44 ton/ha due to high percentage of empty grain. On the other hand, Ciherang as Inbred rice variety well adopted in Indonesia, the potential yield is about 9.71 ton/ha. Ciherang more tolerant to main pest and diseases such as brown plant hopper and tungro compared with hybrid rice varieties. In average, hybrid rice yield of 10.29 ton/ha is about $18.1 \%$ higher compared with inbred rice Variety (Ciherang) with yield of $8.71 \mathrm{ton} / \mathrm{ha}$ (Table 2).

Table2: Yield performance (ton/ha) of 3 hybrid rice (GH-21, SL-8SHS, and Hipa-4) and inbred rice variety as check (Ciherang), Sukamandi 2014.

\begin{tabular}{|l|l|l|l|l|l|}
\hline \multirow{2}{*}{ Variety } & \multicolumn{4}{l}{ On-Farm Yield Wet Paddy (ton/ha) 20\% MC } & Potential \\
\cline { 2 - 6 } & I & II & III & Average & (ton/ha) \\
\hline GH-21 & 9.03 & 9.17 & 9.42 & 9.21 & 10.59 \\
\hline SL8-SHS & 9.60 & 8.56 & 8.67 & 8.94 & 10.83 \\
\hline Hipa-14 & 8.26 & 8.47 & 8.52 & 8.42 & 9.44 \\
\hline Average & $\mathbf{8 . 9 6}$ & $\mathbf{8 . 7 3}$ & $\mathbf{8 . 8 7}$ & $\mathbf{8 . 8 6}$ & $\mathbf{1 0 . 2 9}$ \\
\hline Ciherang & 6.9 & 6.42 & 6.99 & 6.77 & 8.71 \\
\hline
\end{tabular}

Potential rice yield (ton/ha) is based on the each varietal description released by Ministry of Agriculture.

Under integrated rat control management practices, serious rat attack can be reduced significantly and each variety tested in this dem-farm still survive, even though the on-farm yield was significantly lower than the potential yield. The average on-farm yield under heavy rat attack condition, Guo Hao hybrid variety (GH-21) was about 9.21 ton/ha, while SL8-SHS average yield is about 8.94 ton/ha. Among three hybrid varieties tested in this dem-farm, yield of Hipa-14 was the lowest or only about $8.42 \mathrm{ton} / \mathrm{ha}$. Overall average yield of hybrid rice on-farm yield was 10.29 ton/ha or about $30.9 \%$ higher than Ciherang which is the only Inbred rice variety tested as a check variety with yield 6.77 ton/ha in average.

\subsection{Financial Analysis Outputs}

Cost structure of technology validation and verification of hybrid rice farming consisted of three main components such as agricultural inputs, labour and operator, and other (land rent and water management cost). The total cost per hectare was about USD 1,156.46 with yield 8.86 ton/ha or about USD 130.52/ton wet paddy with moisture content (MC) of 22\%). About 50.0\% of total cost production was allocated for agricultural input (USD 578.23) and 27.4\% (USD 316.56) for hard labour cost and about 22.6\% (USD 261.67) for fixed cost that consisted of land rent, land levelling and irrigation fee. Total gross income is USD 2,584.20/ha with net income about USD 1,427.74/ha. While net income of farmers practices is about USD 805.33/ha with yield 5.65 ton/ha (Table 3).

The financial feasibility indicators showed that the large scale full mechanize hybrid rice farming is highly feasible with $\mathrm{RC}$ ratio 2.23 and $\mathrm{BC}$ ratio 1.23 . In other words, every USD 1,000 operational cost will provide gross return or net return about USD 2,230 and USD 1,230 respectively. In addition, MBCR was about 2.98 that indicated for every USD 1.0 additional cost due to adoption of large scale mechanized rice farming will generate additional gross income of about USD 2.98 or USD1.98 which is highly feasible compared with farmer practices that use to grow inbred rice varieties such us Ciherang (Table 3).

\section{CONCLUSION AND POLICY IMPLiCATION}

\subsection{Conclusion}

The Dem-Farm outputs are generally comply most of the technology components and standard operational procedure (SOP) in the implementation of Best Management Practices (BMP) in large scale mechanized rice farming. However, land preparation as one of the BMP components, need further verification and evaluation especially when the soil is under wet condition. Multi-purpose direct seeder with 10 rows perform as expected that can carried out four jobs at the same time such as: seeding, basal fertilizer application, land covering, and ditching for micro canal.

Selection of weeding technique or combination between pre-germinate herbicide spraying, water management, selective post germinate herbicide spraying, and mechanical control need to be applied 
friendly. Early warning system must be continuously exercised to avoid pest and diseases outbreak. Stem borer and rat is two main pests, while BLB and BLS are the main diseases that must be closely monitor and immediately controlled.

In average, potential yield of Keep Long Seeds Ltd hybrid rice promising line is higher compared with hybrid rice promising line from IRRI or about 11.09 ton/ha and 10.12 ton/ha in average, respectively. The financial analysis output showed that this large scale and full mechanize hybrid rice farming is financially feasible with $\mathrm{RC}$ and $\mathrm{BC}$ ratio of 2.23 and 1.23 , respectively. In addition MBCR of 2.97 also showed that the impact of adoption of hybrid rice varieties in large scale mechanized rice farming technology is also financially attractive. In other words, all financial parameters showed that large scale rice farming practices are financially feasible.

\subsection{Policy Implication}

Large scale full mechanize rice farming carried out at low land irrigated rice area in Sukamandi can be considered as frontier rice production model that can be replicated at newly open area in outside Java either in Kalimantan, Sulawesi and Papua. Implementation of this frontier model can be directed with two approaches such as: (1) estate model for newly open area with limited human labor and (2) corporate farming by management consolidation of small land owners into a corporate management or nucleus-plasma system.

\section{KNOWLEDGEMENT}

We would like to express sincerely thanks and appreciation to General Manager of Sukamandi Regional Office PT. Sang Hyang Seri for his strong support and encouragement, and providing rice field of 13.3 ha for demonstration farm (dem-farm) practices. Similarly, we also thanks to workshop specialist for helping us calibrating direct seeders that can perform as expected. Thanks a lot for Agronomist, Entomologist, and Farm Machinery Specialist from Indonesian Centre for Rice Research (ICRR) for their cooperation and working together at the field during dem-farm execution.

Table3: Financial analysis output of large scale full mechanized rice farming, Subang, 2014.

\begin{tabular}{|c|c|c|c|c|c|}
\hline \multirow[t]{2}{*}{ No. } & \multirow{2}{*}{ Description } & \multicolumn{3}{|c|}{ Large Scale } & \multirow{2}{*}{$\begin{array}{l}\text { Farmer } \\
\text { Practices } \\
\text { (USD/ha) }\end{array}$} \\
\hline & & Amount & $\begin{array}{l}\text { Unit price } \\
\text { (USD/unit) }\end{array}$ & $\begin{array}{c}\text { Value } \\
\text { (USD/ha) }\end{array}$ & \\
\hline \multicolumn{6}{|c|}{ I. Expenses } \\
\hline \multicolumn{6}{|c|}{ A. Agricultural Inputs } \\
\hline 1 & Seed $(\mathrm{kg} / \mathrm{ha})$ & 30.00 & 5.00 & 150.00 & 15.00 \\
\hline \multirow[t]{4}{*}{2} & Fertilizer & & & & \\
\hline & \begin{tabular}{l|l} 
a. & Urea $(\mathrm{kg} / \mathrm{ha})$ \\
\end{tabular} & 250.00 & 0.26 & 65.00 & 65.00 \\
\hline & NPK $(\mathrm{kg} / \mathrm{ha})$ & 300.00 & 0.46 & 138.00 & 92.00 \\
\hline & \begin{tabular}{l|l} 
c. & $\mathrm{KCl}(\mathrm{kg} / \mathrm{ha})$ \\
\end{tabular} & 100.00 & 0.50 & 50.00 & 50.00 \\
\hline \multirow[t]{3}{*}{3} & Herbicide & & & & \\
\hline & \begin{tabular}{l|l} 
a. & Logran (sachet/ha) \\
\end{tabular} & 20.00 & 0.58 & 11.60 & - \\
\hline & Ricestar (lt/ha) & 0.50 & 7.92 & 3.96 & 3.96 \\
\hline \multirow[t]{8}{*}{4} & Pestiside & & & & \\
\hline & \begin{tabular}{l|l} 
a. & Reagen $(\mathrm{lt} / \mathrm{ha})$ \\
\end{tabular} & 1.00 & 20.83 & 20.83 & 20.83 \\
\hline & Demenhipo (lt/ha) & 1.00 & 6.67 & 6.67 & - \\
\hline & Nativo (pack/ha) & 1.00 & 5.00 & 5.00 & - \\
\hline & Chemical adhesive (lt/ha) & 1.50 & 3.33 & 5.00 & - \\
\hline & Marshall (sachet/ha) & 3.00 & 0.58 & 1.74 & 1.74 \\
\hline & Furadan $(\mathrm{kg} / \mathrm{ha})$ & 14.00 & 1.25 & 17.50 & 17.50 \\
\hline & Sub Total (USD/ha) & & & 578.23 & 266.03 \\
\hline \multicolumn{2}{|r|}{ B. Labor } & & & & \\
\hline 1 & Tractor for land preparation (USD/ha) & & 125.00 & 125.00 & 125.00 \\
\hline 2 & Direct seeding/transplanting & & 45.97 & 45.97 & 60.61 \\
\hline 3 & Sprying (md/ha) & 6.00 & 4.17 & 25.02 & 33.03 \\
\hline 4 & Rat pumigation (md/ha) & 2.00 & 4.17 & 8.34 & 8.34 \\
\hline 5 & Top dressing fertilizer application (md/ha) & 2.00 & 4.17 & 8.34 & 8.34 \\
\hline 6 & Irrigation canal maintenance (backhoe) & & 6.11 & 6.11 & - \\
\hline 7 & Harvest with Combine Harvester & & 35.31 & 35.31 & 73.68 \\
\hline
\end{tabular}


Frontier Model of Large Scale Full Mechanized Hybrid Rice Farming System at Irrigated Rice Field in Indonesia

\begin{tabular}{|c|c|c|c|c|c|}
\hline 8 & Pest and diseases monitoring (md/ha) & 15.00 & 4.17 & 62.55 & - \\
\hline \multirow[t]{2}{*}{4} & Weeding (3 times) & & & & 90.91 \\
\hline & Sub Total & & & 316.56 & 399.91 \\
\hline \multicolumn{6}{|c|}{ C. Fixed Cost } \\
\hline 1 & Land rent & & 166.67 & 166.67 & 166.67 \\
\hline 2 & GPS guided land leveling & & 85.00 & 85.00 & - \\
\hline \multirow[t]{2}{*}{3} & Irrigation (water mgt) & & 10.00 & 10.00 & 10.00 \\
\hline & Sub Total & & & 261.67 & 176.67 \\
\hline \multicolumn{2}{|c|}{ Total Cost } & & & $1,156.46$ & 842.61 \\
\hline \multicolumn{6}{|c|}{ II. On-Farm Income } \\
\hline 1 & Yield (wet grain, 22\% MC) (ton/ha) & 8.86 & & & 5.65 \\
\hline 2 & Gross Income (USD/ha) & & 291.67 & $2,584.20$ & $1,647.94$ \\
\hline \multirow[t]{4}{*}{3} & Net Income (USD/ha) & & & $1,427.74$ & 805.33 \\
\hline & R/C Ratio & & & 2.23 & 1.96 \\
\hline & B/C Ratio & & & 1.23 & 0.96 \\
\hline & MBCR & & & 2.98 & \\
\hline
\end{tabular}

Note: Large scale rice farming uses hybrid rice varieties, while farmer practices grow inbred rice variety Ciherang.

\section{REFERENCES}

[1] Anuraja, B; P. S. Kanannavar, P. Balakrishnan, B. T. Pujari and M. B. Hadimani. 2013. Laser guided land leveller for precision land development. Department of Farm Power and Machinery College of Agricultural Engineering, Raichur - 584 102, India Email: anu_cae@ rediffmail.com.

[2] Cabangon, R.J; T.P Tuong and N.B Abdullah 2002. Comparing water input and water productivity of transplanted and direct-seeded rice production systems. Agricultural Water Management, Volume 57 (1), pp 11-31.

[3] Chauhan, B.S. 2012. Weed management in direct-seeded rice systems. Crop and Environmental Sciences Division, International Rice Research Institute (IRRI), Los Baños, Philippines.

[4] Department of Soil \& Water Conservation. 2008. Resource conservation through laser levelling. Punjab, India.

[5] M.F. Pampolino, M.F; I.J. Manguiat; S. Ramanathan; H.C. Gines; P.S. Tan; T.T.N. Chi; R. Rajendran; R.J. Buresh. 2007. Environmental impact and economic benefits of site-specific nutrient management (SSNM) in irrigated rice systems. Agricultural Systems.Volume 93, Issues 1-3, March 2007, Pages 1-24

[6] Dobermann, A; C Witt; D Dawe; S Abdulrachman; H.C Gines; R Nagarajan; S Satawathananont; T.T Son; P.S Tan; G.H Wang; N.V Chien; V.T.K Thoa; C.V Phung; P Stalin; P Muthukrishnan; V Ravi; M Babu; S Chatuporn; J Sookthongsa; Q Sun; R Fu; G.C Simbahan; and M.A.A Adviento. 2002. Site-specific nutrient management for intensive rice cropping systems in Asia. Field Crops Research. Volume 74, Issue 1, 15 February 2002, Pages 37-66.

[7] Durga, S.D. 2011. Direct-seeded rice: Potential, performance and problems - A review. Current Advance in Agriculture Science. (2): 77- 88 (December 2011).

[8] Indonesia Centre for Rice Research (ICRR). 2010. Rice Varietal Description. Sukamandi, Subang, West Java, Indonesia.

[9] IRRI. 2013. Land Preparation. Best Management Practices, Rice Knowledge Bank. International Rice Research Institute, Los Banos Philippines.

[10] IRRI. 2013. Water Management. Introduction to Sound Water Management Rice. Knowledge Bank. International Rice Research Institute. Los Banos, Philippines. http://www.knowledgebank.irri.org/rkb/2sound-water-management.html

[11] IRRI. 2003. Laser Levelling Training Manual. Agricultural Engineering Unit, International Rice Research Institute. Los Banos, Philippines.

[12] Johnkutty, I; G. Mathew; J. Mathew. 2002. Comparison between Transplanting and Direct-Seeding Methods for Crop Establishment in Rice. Journal of Tropical Agriculture 40 (2002): 65-66.

[13] Marimin, H.S. 2014. Agent Based Modelling for Investment an Operational Risk Consideration in Palm Oil Supply Change. International of Supply Change Management 1(1): 30-40.

[14] Muhammad, L.A; Adeguna, A.H; Olatinwo, K.B; and Saadu, T.A. 2012. Economic Analysis of Floricultural Plant Production in Kwara State, North Central Negeria. Asian Journal of Agricultural and Rural Development: 2(3): 373-380. 
[15] PT SHS. 2012. Hybrid Rice Variety (SL8 SHS): High Potential Yield and more tolerant to pest and diseases. Hybrid Rice Varietal Description, PT. SHS. Sukamandi, Subang, West Java, Indonesia.

[16] Rickman, J.F., 2002. Manual for laser land levelling, Rice-Wheat Consortium Technical Bulletin Series 5. New Delhi-110 012, India: Rice-Wheat Consortium for the Indo-Gangetic Plains: pp.24.

[17] Stephen, P. H. 2010. The Present Status of Large Scale Farming. Proceeding of the Oklahoma. digital.library.okstate.edu/oas/oas_pdf/v10/p64_66.pdf.

[18] Stephen Sapp. 2012. Large-Scale Agriculture and the Quality of the Social Fabric in Small, Rural Towns in Iowa. www.soc.iastate.edu/sapp/LSFarming.html.

[19] Swaminathan, M. S. 20015. An Ever-green Revolution: Lessons from the Past and Policies for the Future. An International Dialogue on Agricultural and Rural Development in the 21st Century. Beijing, 9 September 2005.

[20] Swastika, D.K.S. 20014. Beberapa Teknis Analisis dalam Penelitian dan Pengembangan Teknologi Pertanian. Jurnal Pengkajian dan Pengembangan Teknologi Pertanian, 7 (1), 90-103.

[21] Tekin Öztekin. 2013. Short-Term Effects of Land Levelling on Irrigation-Related Some Soil Properties in a Clay Loam Soil. Scientific World Journal. Hindawi Publishing Corporation.

Citation: I. M. O. Adnyana et al., "Frontier Model of Large Scale Full Mechanized Hybrid Rice Farming System at Irrigated Rice Field in Indonesia ", International Journal of Research Studies in Agricultural Sciences, vol. 3, no. 11, p. 46-56, 2017. http://dx.doi.org/10.20431/2454-6224.0311004

Copyright: (C) 2017 Authors. This is an open-access article distributed under the terms of the Creative Commons Attribution License, which permits unrestricted use, distribution, and reproduction in any medium, provided the original author and source are credited. 